\title{
PAULO FREIRE NO CONSELHO MUNDIAL DE IGREJAS (CMI)
}

\author{
PAULO FREIRE AT THE WORLD COUNCIL OF CHURCHES (WCC) \\ PAULO FREIRE EN EL CONSEJO MUNDIAL DE IGLESIAS (CMI)
}

Walter Martins de Oliveira*

(iD) https://orcid.org/oooo-ooo1-6532-2121

\author{
REVISTA PEDAGÓGICA \\ Revista do Programa de Pós-graduação em Educação da Unochapecó | ISSN 1984-1566 \\ Universidade Comunitária da Região de Chapecó | Chapecó-SC, Brasil \\ Como referenciar este artigo: OLIVEIRA, W. M. Paulo Freire no Conselho Mundial \\ de Igrejas (CMI). Revista Pedagógica, Chapecó, v. 21, p. 413-430, 2019. \\ DOI: http://dx.doi.org/10.22196/rp.v22io.4916
}

\begin{abstract}
RESUMO: Este artigo teve como objeto evidenciar como Paulo Freire partilhou a vida com seus amigos e colegas no Conselho Mundial de Igrejas (CMI) e, igualmente, esclarecer as razões pelas quais aí escolheu trabalhar. Além de pesquisa bibliográfica, este trabalho buscou as fontes primárias contidas nos documentos que o CMI arquivou sobre Freire, em Genebra, Suíça. Os resultados apontam para a radicalidade da coerência da trajetória de vida do Pedagogo e Filósofo brasileiro. Optou por trabalhar no CMI para, muito melhor, ser fiel e comprometer-se com a causa dos oprimidos e das oprimidas do mundo inteiro, tornando-se, desse modo, cidadão do mundo. Freire e o CMI materializaram grandiosa "simbiose" que proporcionou e continua a proporcionar extraordinária contribuição, em função do resgate daqueles e daquelas que mais precisam. Sua convivência com amigos e colegas no CMI expressa a verdadeira encarnação do ser-mais, da humanização.
\end{abstract}

Palavras-chave: Conselho Mundial de Igrejas. Amorosidade. Coerência. Libertação.

ABSTRACT: This article aimed to highlight how Paulo Freire shared his life with his friends and colleagues in the World Council of Churches (WCC) and also clarified the reasons why he chose to work there. In addition to bibliographic research, this work sought the primary sources contained in the documents that the WCC filed on Freire, in Geneva, Switzerland. The results point to the radical coherence of the life trajectory of the Brazilian Pedagogue and Philosopher. He chose to work in the WCC, much better, to be faithful and to commit himself to the cause of the oppressed and oppressed throughout the world, thus becoming a citizen of the world. Freire and the WCC materialized a great "symbiosis" that provided and continues to provide extraordinary contribution, due to the rescue of those who need it most. His coexistence with friends and colleagues in the WCC expresses the true incarnation of being-more, of humanization.

Keywords: World Council of Churches. Amorosity. Coherence. Release.

RESÚMEN: Este artículo tuvo como objeto evidenciar cómo Paulo Freire compartió la vida con sus amigos y colegas en el Consejo Mundial de Iglesias (CMI)y, también, aclarar las razones por las que allí escogió trabajar. Además de la investigación bibliográfica, este trabajo buscó las fuentes primarias contenidas en los documentos que el CMI archivó sobre Freire, en Ginebra, Suiza. Los resultados apuntan a la radicalidad de la coherencia de la trayectoria de vida del Pedagogo y Filósofo brasileño. Optó por trabajar en el CMI para, mucho mejor, ser fiel y comprometerse con la causa de los oprimidos y oprimidas del mundo entero, convirtiéndose así en ciudadano del mundo. Freire y el CMI materializaron grandiosa "simbiosis" que proporcionó y continúa proporcionando una extraordinaria contribución, en función del rescate de aquellos y de las que más lo necesitan. Su convivencia con amigos y colegas en el CMI expresa la verdadera encarnación del ser-más, de la humanización.

Palabras clave: Consejo Mundial de Iglesias. Amorosidad. La consistencia. La liberación. 


\section{Introdução}

O propósito deste trabalho é evidenciar a vida, a experiência de Paulo Freire no Conselho Mundial de Igrejas, Instituição em que o pedagogo e filósofo brasileiro permaneceu por dez anos, mais especificamente nos anos da década de 1970, do século XX, cumprindo aí seu último estágio como exilado político, quando então retornou ao Brasil, em 1980.

O Conselho Mundial de Igrejas (CMI), com sede em Genebra, Suíça, constituiu-se historicamente em 1948, em Amsterdam, Holanda. Em sua primeira assembleia, na qual foram estabelecidos os critérios referentes a quais igrejas ou denominações religiosas poderiam aderir a ele, o primeiro deles é aceitar Jesus Cristo como Deus e Salvador, segundo o testemunho das Escrituras. Nessa oportunidade se definiram sua constituição, suas tarefas, o comportamento e a posição do organismo em função das decisões políticas, seus programas e pressupostos. Fica claro, igualmente, em sua assembleia de fundação, que o CMI não é uma megaigreja, mas uma comunidade de igrejas, composta de confissões cristãs, com o compromisso de unidade, solidariedade, serviço e apoio. Os recursos recebidos das igrejas-membro, de fundações, instituições e pessoas físicas são destinados a projetos e programas que objetivam a unidade, a missão, a evangelização, a formação ecumênica, a defesa e a promoção conjunta da justiça, a ética da vida, a solução pacífica de conflitos de toda natureza e as propostas alternativas à globalização. $\mathrm{O}$ diálogo inter-religioso e o atendimento aos povos africanos são objetos de especial cuidado do CMI (FREIRE, 1973, 1974).

Portanto, o referido Conselho se traduz, a partir da solidariedade entre os cristãos e cristãs, do compromisso efetivo de luta pela transformação da sociedade nos mais recônditos lugares do mundo, configurando-se no mais significativo organismo de empenho e elevação concreta do espírito ecumênico no Planeta. Atualmente, o CMI reúne cerca de 500 milhões de cristãos e cristãs, agrupando aproximadamente 340 igrejas, denominações e comunidades de igrejas, em sua maioria em países da África, Ásia, América Latina e Caribe, Oriente Médio e Ilhas do Pacífico, totalizando mais de 120 países. O atual secretário geral do CMI é Olav Fykse Tveit, luterano da Noruega, e o Moderador do Comitê Central é Walter Altmann, luterano do Brasil, eleito após a IX Assembleia Geral, realizada em Porto Alegre, Brasil, em fevereiro de 2006. A Igreja Católica não tem nenhum vínculo e não faz parte da organização, mas tem com ela um grupo de trabalho permanente e participa como membro pleno de algumas comissões, como a Comissão de Fé e Ordem, e a Comissão de Missão e Evangelismo. $\mathrm{Na}$ década de 1970, era predominante o número de luteranos e metodistas. Atualmente, propugna-se por um Fórum Cristão Global, em um intento sem vínculos institucionais, de trazer a uma só mesa de diálogo todas as grandes 
famílias cristãs: ortodoxa, católica, anglicana e protestante (incluindo, nesta última, os pentecostais ou evangélicos) (FREIRE, 1973, 1974).

Na busca por elucidar algumas questões referentes à vida, obras e lutas de Paulo Freire, uma delas especificamente, fez-me empreender uma viagem até Genebra, Suíça, para investigar os arquivos de Freire, no CMI. Refiro-me à seguinte questão: Paulo Freire, nos anos em que viveu no continente europeu, escreveu apenas para o CMI, ou quase nada escreveu?

Ocorre que, para melhor esclarecer tal questionamento, Freire, após perseguição e prisão por 72 dias no Brasil, no ano do golpe militar de 1964, exilou-se por pouco tempo na Bolívia, mudou-se para o Chile onde permaneceu por quatro anos e 6 meses. Depois disso, transferiu-se para os Estados Unidos onde trabalhou na Universidade de Harvard por, praticamente, um ano. Por fim, mudou-se para Genebra, Suíça, e por dez anos trabalhou no CMI, assessorando países recém-libertados politicamente no continente africano, como Guiné-Bissau, Angola, São Tomé e Príncipe, Tanzânia, Cabo Verde, Moçambique, entre outros.

Nos dez anos em que permaneceu no Conselho, publicou apenas um único livro, a saber: Cartas à Guiné-Bissau: registros de uma experiência em processo (1978).

Como explicar que alguém tão prolífero em relação à escrita, pudesse publicar apenas um único livro em dez anos? Logo, ele não escreveu? Escreveu apenas em função de seu trabalho junto àquela instituição? Muito escreveu e não publicou? Ou, então, muito escreveu, muito publicou, porém não o fez nos moldes convencionais em forma de livros, a exemplo de sua obra supracitada?

Uma vez embrenhado nos milhares de páginas nos arquivos de Freire em Genebra, dei-me conta da grandeza desse "encontro", ou seja, de um lado um dos mais importantes educadores e pensadores sobre a educação no século XX, e de outro uma Instituição prenhe de espírito ecumênico e solidário, comprometida com a justiça, a ética, a vida, a solução pacífica dos conflitos e transformação da sociedade em todos e quaisquer lugares do planeta.

$O$ resultado desse encontro fundiu-se em benefícios não apenas aos povos africanos que, recém-libertados politicamente, lutavam de modo revolucionário pela sua soberania e coerentemente, viam na educação um dos principais instrumentos de libertação.

Freire, a partir do CMI, no Departamento de Educação daquela Instituição, como consultor especial, é extremamente importante não apenas para os homens e mulheres africanos, mas para pessoas espalhadas pelos mais recônditos lugares do mundo. Prova disso está nas milhares de cartas recebidas e expedidas, arquivadas no Conselho Mundial de Igrejas, em Genebra, Suíça, expressando gratidão, pedidos de pareceres sobre artigos, dissertações e teses, pedidos de emprego nas mais diversas instituições, solicitações de palestras, conferências, 
seminários, encontros presenciais em Genebra e inclusive até mesmo nas conexões, buscando aproveitar o tempo nos aeroportos entre sua chegada e sua saída.

\section{O Conselho Mundial de Igrejas como fonte de pesquisa}

Ao buscar respostas para algumas inquietações pessoais, uma delas já mencionada na introdução deste trabalho, fez-se imperativo, para mim, empreender uma investigação, in loco, no Conselho Mundial de Igrejas (CMI), em Genebra, junto aos arquivos de Freire naquela Instituição. Após vários entendimentos com a arquivista do Conselho e então já com alguns dados e informações previamente definidos, agendei a visita para o mês de abril de 2017 - primavera suíça - mais especificamente para os dias 17 a 21 de abril do mesmo ano.

Constatei a existência de inúmeras caixas. Cada caixa continha várias pastas de arquivos e em cada pasta havia documentos do próprio Paulo Freire, documentos sobre ele, dele com outros autores, entrevistas com Freire, textos referentes ao CMI e cartas recebidas e enviadas, além de textos já publicados de Freire em parceria com outros autores.

Consultei, verifiquei e fotografei, no curso de uma semana, a totalidade de 2.002 (duas mil e duas) páginas. Em vista da grande quantidade e variedade de material recolhido, percebi que seria necessária uma melhor organização; e o que me ocorreu foi dispô-lo da seguinte maneira: (i) textos de autoria de Paulo Freire; (ii) textos de Paulo Freire em parceria com outro autor; (iii) textos de outro autor sobre Paulo Freire; (iv) textos de outro autor sobre o CMI e (v) cartas de Paulo Freire (recebidas e expedidas).

Da totalidade do material recolhido junto ao $\mathrm{CMI}$, nos arquivos de Paulo Freire, 440 (quatrocentas e quarenta) páginas que se referem a textos de autoria do próprio Freire, foram selecionadas por mim, uma vez que entendi serem importantes para o esclarecimento das questões que me inquietavam.

Parece-me oportuno informar que todo esse material, disponível nos arquivos do CMI, encontra-se hoje, da forma como trouxe para examinar detidamente, no Instituto Paulo Freire com sede na cidade de São Paulo, à rua Cerro Corá, 550 - Alto da Lapa. Com muita satisfação e alegria entreguei, em mãos, uma cópia do referido acervo ao Professor Doutor Moacir Gadotti, presidente de honra do Instituto.

A propósito, em Pedagogia da esperança (FREIRE, 2015), ao relatar o aparecimento de sua obra Pedagogia do oprimido, em setembro de 1970, em Nova York, e sua imediata tradução nas mais diversas línguas, suscitando curiosidade, críticas a favor e contra, Freire (1970) menciona as cartas que recebia trazendo a expressão da curiosidade que o livro despertava, a leitura que dele se fazia, sua aceitação e também a recusa. 
Contudo, Freire lamenta não as ter guardado sistematicamente, julgando-as como importantes correspondências. Diante disso, é possível depreender que outros possíveis relatórios de seus encontros pessoais com universitários, operários e membros das mais diversas instituições etc., bem como outros tantos conteúdos escritos resultantes de seus debates, ensaios, reflexões, palestras etc. sobre os mais diversos assuntos, igualmente tenham se extraviado, desviados do caminho dos arquivos de Freire no CMI.

\section{Freire e sua opção pelo Conselho Mundial de Igrejas}

Segundo Andreola e Ribeiro (2005), em 1969, Freire já havia decidido deixar o Chile e como houvera recebido dois convites de trabalho, ou seja, o primeiro proposto pela Universidade Americana de Harvard e o segundo, logo a seguir, do CMI; preferiu o segundo. Contudo, mesmo preferindo o CMI, propôs aos americanos sua permanência naquela universidade por um ano, fazendo palestras, seminários etc. Freire considerava muito importante viver por determinado tempo nos Estados Unidos. Diante disso, sua proposta se resumiu em ficar o ano de 1969 em Harvard e mudar-se para a sede do referido Conselho em Genebra, Suíça, no início de 1970, o que fora aceito pelos dois lados.

Para elucidar sua preferência pelo CMI, faz-se oportuna a entrevista de Freire ao Pasquim, quando esclarece:

Eu preferia vir para o Conselho, porque o problema de ser professor para mim não se coloca. Eu me acho professor numa esquina de rua. Eu não preciso do contexto da universidade para ser um educador. Não é o título que a universidade vai me dar que me interessa, mas a possibilidade de trabalho. E naquela época eu sabia que o Conselho ia me dar a margem que a universidade não me daria. Eu temia, ao deixar a América Latina, perder o contato com o concreto e começar a me meter dentro de bibliotecas e começar a operar sobre livros o que não me satisfaria e me levaria à alienação total. Não me interessa passar um ano estudando um livro, mas um ano estudando uma prática diretamente. $\mathrm{O}$ Conselho me dava essa oportunidade. (ANDREOLA; RIBEIRO, 2005, p. 52).

Depreende-se, seguramente, que aceitar o convite do Conselho Mundial de Igrejas e não ao que lhe viera de Harvard, significava a coerência com o lugar social, ou seja, não perder de vista concretamente a realidade dos oprimidos.

Ocorre que, para Freire, escutar o povo, valorizar suas palavras, partir sempre de seu nível de consciência e de sua percepção da realidade, estabelecer com ele 
verdadeiro diálogo, consistem o alicerce do processo de libertação e, portanto, da luta por uma sociedade em que, segundo ele próprio, se constitui em "[...] um mundo em que seja menos difícil amar” (2011, p. 253).

Fica claro que Freire, quando optou pelo CMI, coloca como prioridade assumir o compromisso com o lugar social dos oprimidos. Isto significa renunciar às estruturas, ao poder e aos privilégios que estas oferecem, colocar-se ao lado dos oprimidos, conhecer a realidade, escutar as palavras e, de modo especial, escutar o silêncio deles, uma vez que a estes negaram o direito de falar.

Paulo Freire, ao optar por trabalhar no CMI, vê no Conselho, conforme suas próprias palavras em entrevista ao Pasquim, a oportunidade de estudar uma prática diretamente, evitando desse modo alienação total, ao enfurnar-se em uma biblioteca e produzir a partir dos livros (ANDREOLA; RIBEIRO, 2005).

Ao tomar sua decisão, entende que necessário e urgente é resgatar o oprimido; mas, para que isso ocorra, este não pode ser um mero destinatário, mas sujeito histórico que sonha e luta por uma sociedade igualitária, em que não haverá nem ricos nem pobres, mas justiça, comunhão e participação.

Contudo, tal resgate em sua eficácia, necessita da ciência, da teoria que ilumina a prática, a realidade e desvela o sistema opressor em seus engodos, suas maquinações e contradições. Portanto, foi nessa perspectiva que Freire pôde se ver útil à sociedade e como militante, não como perito, especialista ou expert.

O CMI como instituição que congrega igrejas cristãs predispostas e comprometidas com a solidariedade, o serviço, o apoio, a formação ecumênica, a justiça social, a solução pacífica dos conflitos e o diálogo inter-religioso, significaria a encarnação de sua coerência, harmonia entre suas ideias e sua prática. Isto significa afirmar a possibilidade de, conforme Andreola e Ribeiro (2005), acelerar o processo de construção de Pedagogia do oprimido como projeto histórico e não apenas como um livro, por mais importante obra que pudesse sê-lo e como, de fato, o foi.

A partir do CMI, portanto, sua obra clássica, encontrou-se em solo muito fértil para sua recriação nos mais recônditos lugares do mundo e das mais diversas maneiras. Ele próprio, Freire, em suas declarações e depoimentos, esclarece sua intuição de que, escolhendo o Conselho, este abriria as portas necessárias para que o mundo acolhesse sua proposta.

E assim realmente o foi. O Conselho o catapultou para o mundo, não o prendendo no burocratismo da Instituição. Lançou-o efetivamente para o mundo e, de modo prioritário, para o continente africano, que proporcionou a ele condições dignas de trabalho, tanto de modo individual quanto em equipe, para que pudesse realizá-lo e como 
realmente o fez, em um sem número de países em todos os continentes, tornando-se cidadão do mundo.

Freire revela, em Freire e Guimarães (2000), uma espécie de insegurança sobre que ambiente o aguardaria em Genebra. Porém, igualmente afirma que, em seus dez anos no Conselho Mundial de Igrejas, jamais foi questionado, nunca foi chamado pelos seus superiores para algum tipo de alinhamento ideológico ou ponto de vista religioso. Confessa também nunca ter sido tão livre para trabalhar quanto o fora no Conselho.

Nesse sentido há uma observação que, a meu juízo, parece importante considerar, a saber: obviamente o Conselho Mundial de Igrejas é uma Instituição eminentemente religiosa, portanto, qual deveria ser sua postura referente à utilização das categorias marxistas? $\mathrm{E}$, por outro lado, como Freire, um homem de fé e até teólogo (como ele próprio afirmara), utiliza-se na luta pela libertação do povo, de categorias marxistas? Seria verdadeiro considerar que, quando viveu seus dez anos em Genebra, foi o tempo em sua vida em que mais se aproximou das categorias de Karl Marx? Seria possível afirmar que, em vista de ter escolhido trabalhar em um organismo religioso ecumênico, de abrangência mundial, transformou-se em ateu? Necessitou camuflar sua fé, uma vez que o CMI comporta grande diversidade de igrejas cristãs?

À luz de sua obra Pedagogia do oprimido, Freire apresenta sua pedagogia libertadora afinada com a perspectiva marxista, uma vez que, como práxis revolucionária, faz do oprimido agente desvelador do mundo de opressão, no compromisso com a transformação da realidade.

Acontece que Freire, desde muito cedo em sua vida, movido pelo seu cristianismo revolucionário, foi aos trabalhadores e trabalhadoras da cidade e do campo de sua terra natal e estes o levaram Marx; e, uma vez tendo encontrado Marx, não viu a necessidade de parar de se encontrar com Cristo. Estar com Cristo e com Marx não contradita nada em suas convicções pessoais, ou seja, não se coloca em questão ser um cristão e, ao mesmo tempo, ser um marxista. Afirma que é um ser humano em processo permanente de formação. Sente-se muito bem com Cristo e Marx. É muito grato a Marx, pois, por meio dele, alcançou outros caminhos para melhor compreender o evangelho, o que lhe proporcionou descobrir muitas coisas que estavam escondidas, veladas pela ideologia burguesa.

Nesse sentido, em conversa-entrevista concedida à Lígia C. M. Leite e Antônio Faúndez, no dia 8 de dezembro de 1979, em material recolhido junto ao CMI, em Genebra, Paulo Freire esclarece:

Talvez o que eu pudesse dizer, repetir o que tenho dito em certas entrevistas, que eu acho expressa bem a minha experiência, é o seguinte: indiscutivelmente, eu fui, na minha juventude, ao camponês e ao operário da 
minha cidade, movido pela minha opção cristã. O que eu não renego. Chegando lá, a dramaticidade existencial dos homens e mulheres com quem eu comecei a dialogar me remete a Marx. É como se os camponeses e operários me tivessem dito: "Paulo, vem cá, você conhece Marx?” Eu fui a Marx por isso. $E$ indo a Marx, eu começo a me surpreender com a alegria por ter encontrado Marx entre os camponeses e entre os operários. Quer dizer, certo tipo de análise, como aquela do meu pedagogo que eu citei no começo, em que ele me chamava a atenção para as coisas materiais em que sua consciência se formava e se reformava [...]. Comecei a ver uma certa radicalidade original do pensamento marxista lá na área camponesa, de analfabetos. Então comecei a ver: puxa, esse cara é sério! Não quero dizer que eu sou hoje um expert em Marx, ou que eu sou um marxista. Por uma questão até de humildade. Eu acho que é muito sério dizer alguém ser marxista. É preferível dizer que eu estou tentando tornar-me. E a mesma coisa em relação à minha opção cristã. Eu sou um homem em procura de tornar-me cristão. Quanto mais eu me encontrei com Marx, direta ou indiretamente, tanto mais eu entendi os evangelhos que eu lia antes com uma diferente interpretação. Quer dizer, no fundo, Marx me ensinou a reler os evangelhos. Para muita gente isso é absurdo. Para certos marxistas mecanicistas, que para mim não entenderam Marx, e que não só distorcem, mas obstaculizam o desenvolvimento do pensamento marxista, para esses eu sou um contraditório, e não vou deixar de ser jamais um idealista, representante de uma pedagogia burguesa. Para certo tipo de cristão mecanicista também, tão reacionário quanto esses pseudomarxistas, eu sou um endemoniado contraditório. Eu não vejo nenhuma contradição à minha opção cristã pretender uma sociedade que não se funda na exploração de uma classe por outra. Em última análise, devo dizer que, tanto a minha posição cristã quanto a minha aproximação a Marx, ambas jamais se deram ao nível intelectualista, mas sempre referidas ao concreto. Não fui às classes oprimidas por causa de Marx. Fui à Marx por causa delas. O meu encontro com elas é que me fez encontrar Marx e não o contrário.

Depreende-se que, para Freire, Marx contribuiu para que melhor pudesse discernir quem verdadeiramente é o Deus do povo na perspectiva libertadora.

O que parece ficar cada vez mais claro é que Freire vai, no curso de sua vida, progressivamente incorporando 
o Marxismo. Esclarece melhor quando, ainda na mesma entrevista, afirma: "É preferível dizer que eu estou tentando tornar-me" um marxista.

A partir do CMI, por conta da missão que Freire recebera junto aos países do continente africano, foi exigido que ele deixasse de se preocupar com a teoria explícita em seus escritos para atender às prioridades da prática, ao intenso e urgente trabalho com aquelas comunidades dos países em reconstrução nacional. Nesse sentido, pode-se inferir que Freire é muito mais marxista em Cartas à Guiné-Bissau (1978) do que em Pedagogia do oprimido (1987). Logo, é possível depreender que Freire não se torna nem mais nem menos cristão, nem mais nem menos marxista, pelo simples fato de se encontrar na condição de exilado, trabalhando em um órgão eminentemente religioso.

É provável que sua preocupação não seja mais com a teoria explícita sobre Marx, mas com a de encarná-la na prática, quando se constata que em Pedagogia do oprimido (1987) cita Marx 23 vezes e em Cartas à Guiné-Bissau (1978), apenas quatro vezes. É apropriado lembrar aqui que, em Cartas à Guiné-Bissau, o contexto é de efetiva contundência, isto é, aquele país estava em plena revolução. Significa afirmar que a realidade da missão que recebera do CMI coloca-o visceralmente na prática, na exigência real de praticar uma teoria revolucionária na educação e o Marxismo oferecia as ferramentas para tal empresa, o que lhe fez sentir-se plenamente à vontade.

Caminhar, por exemplo, com o povo de Guiné-Bissau, uma nação em reconstrução, recém-libertada politicamente, portanto, com problemas próprios de uma sociedade revolucionária, com necessidades urgentes de conhecer mais, de sistematizar o que já sabia, de transformar e de construir, exigiu-lhe, seguramente, mais do que em qualquer outro momento de sua vida, pôr a teoria em prática. Para melhor compreender esta afirmação, há que se perguntar: o que, de fato, fez com que a realidade de Guiné-Bissau fosse diferente? Qual o sentido da diferença desse contexto em relação a qualquer outro em que Freire já havia vivido e trabalhado, inclusive no brasileiro?

A explicação da especificidade guineense, em minha modesta visão, parece profundamente esclarecedora nas palavras do próprio Freire (2014, p. 129), quando assevera:

Em Cabral eu aprendi uma porção de coisas, digo em Cabral significando também com Cabral, eu aprendi um bando de coisas, eu confirmei outras coisas de que eu suspeitava, mas eu aprendi, por exemplo, uma coisa que é a necessidade que tem o educador progressista e o educador revolucionário. Eu faço uma distinção entre um e outro: para mim um educador progressista é aquele que trabalha numa sociedade burguesa de classe como a nossa, por exemplo, e tem o sonho que transcende, que vai mais além de fazer a 
escola melhor, mas que é preciso fazer, porque ele sonha mesmo é com a transformação radical da sociedade burguesa, numa sociedade socialista. Esse para mim é um educador progressista. $\mathrm{O}$ educador revolucionário é aquele que já se encontra situado, histórica e socialmente, na sociedade em processo, em um nível mais avançado.

Freire esclarece, na mencionada entrevista do dia 8 de dezembro de 1979, em Genebra (LEITE; FAÚNDEZ, 1979), que, por meio de seus textos, trabalhava a teoria marxista sem citar Marx; porém, o fazia em linguagem que o povo entendia. Para que fique mais claro como isso se dava, é conveniente aqui citá-lo quando se refere a um de seus textos intitulado $O$ processo produtivo:

Os meios de produção e os trabalhadores constituem o que se chamam forças produtivas de uma sociedade. A produção resulta da combinação entre os meios de produção e a força de trabalho. Para compreender uma sociedade é importante saber como se combinam os meios de produção e a força de trabalho. É preciso saber a natureza das relações sociais que se dão na produção. Se são relações de exploração ou se são relações de igualdade e de colaboração entre todos. $\mathrm{Na}$ época colonial, as relações sociais de produção eram de exploração. Por isso, tinham que ser violentas. Os colonialistas apoderaram-se dos meios de produção e da nossa força de trabalho. Eram donos absolutos das terras brutas, das matérias-primas, das ferramentas, das máquinas, dos transportes e da força de trabalho dos trabalhadores. Nada escapava ao poder e ao controle. Quando falamos hoje em reconstrução nacional para criar uma sociedade nova estamos a falar numa sociedade realmente diferente. De uma sociedade em que as relações sociais de produção já não serão de exploração, mas de igualdade e colaboração entre todos.

Freire incorpora a teoria marxista de forma consciente e crítica, renovando-se permanentemente, com interesse principal no homem e na mulher e sua realização ética, espiritual e cultural. Por isso, lança mão da sociologia marxista como instrumento de análise socioeconômica em suas obras e práticas, com o propósito de conduzir o povo a novas e libertadoras interpretações do passado e do presente, em vista do fortalecimento de sua luta por um mundo melhor. E isto não lhe provoca atrito com sua fé em Cristo.

Freire, em sua concepção de Deus como presença na história e que, de forma alguma, impede ao ser humano 
de fazer a história de sua libertação, entende que o fato de se utilizar de categorias marxistas em seu trabalho com o povo não lhe exige ser ateu. Seguramente, não tinha a preocupação em sustentar a teoria marxista nem mesmo assumir uma postura proselitista no sentido de defender a Igreja Católica. O que buscou, e de forma radical, foi a transformação da sociedade, a superação da realidade injusta a partir dos próprios oprimidos e oprimidas. Daí a coerência do título de sua principal obra Pedagogia do oprimido e não "pedagogia para o oprimido". Disso resulta que não vê sentido e, até mesmo rejeita energicamente, o dualismo entre mundanidade e transcendentalidade. Vale transcrever, aqui, para melhor elucidar sua rejeição à referida dicotomia, as palavras do próprio Freire (2014, p. 46), quando afirma:

Não há transcendentalidade sem mundanidade. Eu tenho que atravessar a mundanidade para alcançar a transcendentalidade. $\mathrm{E}$ essa coisa me irrita muito. E, na minha juventude, eu nunca confundi esse sermão com o recado de Cristo. Eu não tive que sair do time, mudar de time. Mas, hoje, vocês observem o que vem sendo a Igreja no Brasil, para não falar na América Latina toda[...]. A gente vê o papel, o compromisso histórico que a Igreja foi assumindo no Brasil, no momento em que ela foi virando profética de novo. No começo, ela foi profundamente tradicional, depois ela foi moderna ou modernizada, que é uma maneira inteligente de ser mais eficientemente tradicional. Finalmente, grandes setores da Igreja no Brasil encarnam exatamente a postura profética, de quem denuncia, de quem anuncia, de quem não tem medo da morte.

Seria verdade que o período de seu exílio na Suíça foi o momento de sua vida em que mais se aproximou do Marxismo?

Constata-se que não há razões sólidas para garantir que Freire se aproximou mais das ideias de Marx na década de seu exílio na Europa. Em A importância do Ato de Ler: três artigos que se completam (1989), cita Marx uma vez; em Ação cultural para a liberdade (1981a), 18 vezes; em Cartas à Guiné-Bissau: registros de uma experiência em processo (1978), quatro vezes; em Conscientização: teoria e prática da libertação (1979), duas vezes; em Educação e mudança (1981b), duas vezes; em Extensão ou comunicação? (1983), duas vezes; em Medo e ousadia - O Cotidiano do Professor (1986), 19 vezes; em Pedagogia da autonomia (2002), três vezes; em Pedagogia da esperança (2015), 23 vezes; em Pedagogia do oprimido (1987, 2011), 23 vezes; e em Professora sim, tia não (1997), uma vez. Como se pode comprovar, as citações de Marx estão presentes em suas principais obras. Essa verdade indica que a teoria marxista 
fez parte de sua história de vida e de sua trajetória intelectual desde o início de sua carreira. Ocorre que, conforme já mencionado, em entrevista a Lígia Chiappini Moraes Leite e António Faúndez, no dia 8 de dezembro de 1979, em Genebra, graças ao seu trabalho como consultor no CMI junto aos países do continente africano, mais especificamente Guiné-Bissau, São Tomé e Príncipe, Cabo Verde, Angola e Moçambique, Freire necessitou seguramente, mais do que em qualquer outra época em sua vida, colocar em prática as teorias de Marx, o que resultou em maior evidência no que concerne à sua postura marxista.

Freire, a partir do CMI, sentiu-se motivado, redescobrindo nos lugares onde atuava, sua própria terra. Na África, por exemplo, sentiu-se no Brasil. Naqueles homens e mulheres africanos com quem muito intensamente trabalhou, igualmente o remitiam a Marx tal qual quando de sua juventude em sua cidade no nordeste brasileiro, o mesmo lhe ocorria por meio dos operários e camponeses brasileiros.

Em Cartas à Guiné-Bissau, Freire (1978), muito poeticamente, expressa-se que, pisar pela primeira vez no chão africano, sente-se nele como quem voltava e não como quem chegava. Tudo ali lhe parecia como que velhas conhecidas que com ele e dele falavam. Referia-se às mínimas coisas daquela terra, referia-se a tudo o que ali via, ouvia e sentia. Foi tomado por inteiro e por tudo naquela realidade, o que lhe fez perceber ser mais africano do que havia pensado sê-lo.

Não é exagerado afirmar que isso somente lhe foi possível e da forma e com o espírito com que lhe ocorrera graças ao Conselho Mundial de Igrejas.

\section{Freire e o seu jeito de ser no Conselho Mundial de Igrejas}

Ao que tudo indica, conviver com Freire era uma das tarefas mais fáceis e agradáveis possíveis. Apesar da contundência de seus escritos e de suas palavras, assim como em sua prática e no curso de sua vida, viveu e enalteceu o amor. Tem o amor como dimensão essencial. Com veemência repeliu a ideia de que o amor é conceito burguês.

Em Andreola e Ribeiro (2005), afirma ser capaz de amar enormemente qualquer povo. Seu olhar é de amorosidade e encantamento. Em sua obra máxima, Pedagogia do oprimido, afirma que o alicerce do diálogo é o amor e que o ato de amor está no compromisso com a causa do oprimido e este compromisso por ser amoroso é também diálogo. $\mathrm{O}$ amor é um ato de coragem. Por isso, a revolução é um ato de amor (FREIRE, 1987).

Para o secretário-geral do Conselho Mundial de Igrejas, Reverendo Doutor Konrad Raiser (Tribute to Paulo Freire, 1921 - 1997 - material recolhido junto aos arquivos do CMI), Freire, como membro da Igreja Católica Romana, nunca deixou de afirmar sua fé cristã e seu compromisso 
com o ecumenismo; influenciou fortemente a Teologia da Libertação e prestou profundo apoio aos movimentos sociais e às Comunidades Eclesiais de Base (CEBs). Em nome daquela Instituição, agradece a Deus pela vida e extraordinária contribuição, não apenas quanto à teoria e à prática da educação mas também pelo desenvolvimento das formas mais humanas que sedimentou. Afirma ainda o secretário geral que Freire será sempre lembrado por seus amigos do CMI com afeição e respeito.

Tal homenagem, seguramente, reafirma o alicerce da perspectiva humanista da pedagogia libertadora de Freire e sua postura otimista em relação ao ser humano que, não apenas está no mundo, mas igualmente com o mundo, projetando-se para além de si mesmo, o que assegura, para além da mundanidade, a transcendentalidade dos homens e das mulheres.

Segundo Coelho (2011), Freire, após receber a carta de anistia, queria mesmo era voltar para sua terra querida e, então se preparou para o retorno ao Brasil, após 16 anos de exílio, sendo dez deles no CMI, em Genebra, Suíça. Ainda para Coelho, na oportunidade da despedida de Freire, seus amigos e colegas elaboraram um documento escrito ${ }^{1}$ em forma de bilhetes, expressando afeição e respeito vivenciados e construídos ao longo dos anos de convivência naquela Instituição.

A seguir, conforme menciona Coelho (2011), seguem alguns exemplos da exteriorização dos sentimentos de seus amigos e colegas no momento de despedida de Freire.

Paulo, você tem contribuído tanto com o CMI e significou muito pessoalmente para muitos de nós. Obrigado pela sua colaboração (Guinea Bissau, Cape Verde!), e todos os meus melhores desejos.

Continuaremos a ocupar-nos da Educação no CMI, da família, dos adultos, dos iletrados, dos pobres e talvez até dos ricos, mas nunca vai ser a mesma coisa do que foi enquanto você ficou conosco. Graças a você e agradeça também à sua família pelas bênçãos. Espero que a sua oficina antiga não tenha feito a vida difícil demais; pelo menos, esse era o objetivo.

Paulo, você nos ensinou a ser pessoas da mesma aldeia, com a esperança e o desejo de compartilhar e criar um futuro em comum, sempre criando uma atmosfera de curiosidade e consciência crítica. Eu quero que você continue sendo parte da nossa aldeia.

Eu não tenho palavras profundas. Só deixe-me cumprimentar como um irmão. Obrigado.

Obrigada por você ser autêntico, simples e sempre um grande guerreiro.

Lamentamos profundamente te ver partir, Paulo, mas naturalmente eu estou muito feliz porque você e a sua família, podem finalmente
$1 \mathrm{O}$ referido documento não mais faz parte dos arquivos de Freire no CMI. Segundo Coelho (2011), hoje, encontrase no acervo do Instituto Paulo Freire no Brasil. 
voltar ao seu país e a sua gente! Todos os meus melhores desejos para sua vida futura e o seu trabalho.

Só lamento uma coisa: não ter te conhecido melhor enquanto você esteve aqui! Depois de todos estes anos fora do seu país, eu espero que você agora se torne um profeta em sua terra. Uma pergunta: como é que a educação pode ser não só uma maneira de conhecer e acumular, mas também uma maneira de ser? Eu não sei! Tudo de melhor para você.

Mesmo sendo Suíça, tem poucos valores aos quais eu possa me identificar ... Mas um dos sonhos que eu tenho é a montanha, que convida a sonhar com a liberdade. Obrigada por tudo o que eu aprendi de você e pelos seus sonhos de liberdade. Abraço.

Eu tenho admirado muito seu exemplo e a sua modéstia, a sua profundidade e a sua perspectiva positiva. Meus melhores desejos vão com você enquanto você vai embora.

Querido Paulo. A sua amizade, sua sabedoria e sua modéstia tem sido uma fonte de inspiração e de alegria para mim. Vou sentir saudades de você. Desejo muitas coisas boas para o seu futuro no Brasil. Quando eu escutar ou ler as palavras "pedagogia" e "oprimido", vou me lembrar de você. Com solidariedade e esperança.

Querido Paulo, Tempus fugit e agora você vai nos deixar! Eu estou feliz porque conheci você - mesmo se foi só em encontros curtos - e estou orgulhoso do seu trabalho que tem influenciado milhões de pessoas e que vai influenciar milhões mais. Tomar consciência significa ficar mais perto de Deus e das suas pessoas. Você tem contribuído tanto pelo despertar do mundo inteiro! Rezo por você e uma lembrança nas minhas missas. Pax christi sit semper tecum!

Querido Paulo, quando nos conhecemos na Tanzânia no ano de 74, eu não sabia que nós seríamos eventualmente colegas. De fato, provavelmente eu vi mais de você lá, em pessoa, do que eu vi aqui! No entanto, eu tenho conhecido muitas coisas sobre você nestes anos, enquanto eu leio os seus livros, eu sei que estou muito agradecida por ter conhecido alguma coisa sobre o homem que você é além das suas palavras. Vá com Deus.

Querido Paulo, a grandeza do seu trabalho é que suas brilhantes ideias chegaram do mais profundo do seu povo e a grandeza da sua decisão é que você vai voltar ali. A Comissão Médica Cristã, certamente, aprendeu muito da sua dialética do pensamento e da prática. Deus abençoe você e sua família no futuro. Bênçãos. 
Querido Paulo quantas vezes tenho ouvido a palavra "conscientização"? Quantas vezes eu tenho conhecido pessoas, amigos, camaradas, tentando viver com as suas ideias? Quantas vezes temos feito os nossos próprios descobrimentos? Estimulados pelo seu pensamento, aprendemos, lutamos e aprendemos novamente. Quantas vezes o seu nome tem sido pronunciado durante as minhas viagens pelo mundo inteiro? Você vai embora, mas fica com o nosso trabalho na educação, assim como antes. Com minha gratidão profunda e minha admiração.

Querido Paulo, primeira vez que eu te vi foi em uma conferência em Bergen, Holanda. Foi organizada pelo CMI e você fez uma apresentação muito boa lá. Eu te observei enquanto você falava nas plenárias. Ficamos muito satisfeitos em ver você falar sobre as novas perspectivas da educação cristã. As suas contribuições foram uma revelação para mim. Suas ideias do que acontece na sala de aula de uma escolinha tradicional avivaram muitas memórias do meu passado, mas o que me perturbou, foi ter me apercebido que eu também estava transmitindo conhecimentos na minha escola em Tanzânia, da mesma maneira na qual eu os tinha recebido com o sistema colonial. Eu tenho aprendido muito dessa experiência. Muito obrigada por ter mudado os meus pressupostos. Muito obrigada por tudo que você me deu pessoalmente, ao meu país Tanzânia e certamente às tantas outras pessoas em África, mediante as suas ideias, sua filosofia educacional e o seu envolvimento prático na recriação das experiências educacionais libertadoras. Espero ver mais de você em África no futuro. Você se converteu em nosso aliado natural. Precisamos de você. Deus te abençoe e a sua família, enquanto você continua trabalhando com a sua gente. Quando você voltar à América Latina e eu chegar ao México, deixe-me dizer que você vai conhecer muitos discípulos lá que só tem lido seus livros e que você também não os conhece pessoalmente. $\mathrm{O}$ essencial é que a "Pedagogia do oprimido" tenha sido assimilada, e que continue sendo, um método de libertação mediante a conscientização. Obrigado em nome dos seus irmãos da África.

Segundo Mendonça (2008), para Freire o ser humano está no mundo e com o mundo. É um ser capaz de relacionar-se; é um ser em comunicação, é transcendente; é um sujeito de relações para o qual o diálogo é condição existencial. As relações dos seres humanos com o mundo e com eles próprios, alicerçadas no diálogo, asseguram o 
seu ser-mais, a sua humanização. Portanto, graças à radicalidade de sua coerência, é possível depreender o homem que fora e quão privilegiados e privilegiadas foram aqueles e aquelas que com Freire conviveram, partilhando o cotidiano, a exemplo do que ocorrera no CMI.

\section{Considerações finais}

Paulo Freire já estava vivendo em Brasília quando o golpe militar, em 31 de março de 1964, foi anunciado. Como o seu método de alfabetização de adultos foi considerado subversivo pelos repressores, Freire foi perseguido e preso. Contudo, sua prisão somente ocorrera graças à sua coerência ao decidir ficar no país, assumindo o peso da responsabilidade.

Quando decidiu sair do Chile poderia ter optado confortavelmente em aceitar o convite da universidade estadunidense de Harvard que, aliás, chegou-lhe primeiro. Porém, ao se decidir pelo segundo convite, Freire, mais uma vez deu testemunho da coerência radical de sua trajetória, isto é, sua fidelidade à causa dos oprimidos. Escolher trabalhar no CMI significava, naquele momento histórico, não abrir mão de um projeto de libertação no qual oprimidos do mundo inteiro e não apenas os do Brasil e da América Latina, efetivamente, são sujeitos históricos.

Uma vez que Freire optou pelo CMI e não por Harvard, subjetivamente e pelas razões já aqui expostas, foi o que entendeu ser o melhor para ele. Todavia, o melhor para ele implicaria o melhor que ele próprio poderia oferecer aos oprimidos em todos os lugares do mundo.

Intuir que o CMI iria, muito melhor, proporcionar a ele estar com os oprimidos, significa o verdadeiro testemunho de amor ao mundo. Amor enquanto condição sine qua non para que o diálogo aconteça. E para Freire (2011), onde quer que estejam os oprimidos, o gesto concreto do amor consiste em comprometer-se com sua libertação.

\section{Referências}

ANDREOLA, Balduino Antonio; RIBEIRO, Mário Bueno. Andarilho da esperança: Paulo Freire no Conselho Mundial de Igrejas. São Paulo: ASTE, 2005.

COELHO, Edgar Pereira. Pedagogia da correspondência: Paulo Freire e a educação por cartas e livros. Brasília: Liber Livro, 2011.

FREIRE, Paulo. Education for awareness a talk with Paulo Freire. Risk, Genebra, v. I, p. 6-7, 1970.

FREIRE, Paulo. Education, liberation and the church. Magazine Study Encouter, Genebra, v. IX, n. 1, p. 1-16, 1973 . 
FREIRE, Paulo. Las iglesias, la educación y el proceso de liberación humana en la historia. Buenos Aires: Asociación Editorial La Aurora, 1974.

FREIRE, Paulo. Cartas à Guiné-Bissau: registros de uma experiência em processo. 2. ed. Rio de Janeiro: Paz e Terra, 1978.

FREIRE, Paulo. Conscientização: teoria e prática da libertação. Uma introdução ao pensamento de Paulo Freire. São Paulo: Cortez \& Moraes, 1979.

FREIRE, Paulo. Ação cultural para a liberdade. 5. ed. Rio de Janeiro: Paz e Terra, 1981a.

FREIRE, Paulo. Educação e mudança. 12. ed. Rio de Janeiro: Paz e Terra, 1981b.

FREIRE, Paulo. Extensão ou comunicação? 8. ed. Rio de Janeiro: Paz e Terra, 1983.

FREIRE, Paulo. Medo e ousadia - O Cotidiano do Professor. Tradução de Adriana Lopez; revisão técnica de Lólio Lourenço de Oliveira. Rio de Janeiro: Paz e Terra, 1986. (Coleção educação e Comunicação, v. 18).

FREIRE, Paulo. Pedagogia do oprimido. 29. ed. Rio de Janeiro: Paz e Terra, 1987.

FREIRE, Paulo. A importância do Ato de Ler: três artigos que se completam. São Paulo: Cortez, 1989.

FREIRE, Paulo. Professora sim, tia não. Cartas a quem ousa ensinar. São Paulo: Olho d'água, 1997.

FREIRE, Paulo. Pedagogia da autonomia. Rio de Janeiro: Paz e Terra, 2002.

FREIRE, Paulo. Pedagogia do oprimido. 50. ed. rev. e atual. Rio de Janeiro: Paz e Terra, 2011.

FREIRE, Paulo. Pedagogia da tolerância. 2. ed. Rio de Janeiro: Paz e Terra, 2014.

FREIRE, Paulo. Pedagogia da esperança: um reencontro com a pedagogia do oprimido. 22. ed. São Paulo: Paz e Terra, 2015 .

FREIRE, Paulo; GUIMARÃES, Sérgio. Aprendendo com a própria história II. São Paulo: Paz e Terra, 2000.

LEITE, Lígia Chiappini. Moraes; FAÚNDEZ, António. Encontro com Paulo Freire. Revista Educação e Sociedade. Genebra: IDAC, 8 dez. 1979. 
MENDONÇA, Nelino Azevedo de. Pedagogia da humanização: a pedagogia humanista de Paulo Freire. São Paulo: Paulus, 2008.

Recebido em: 09/05/2019 Aprovado em: 09/10/2019 Publicado em: 20/12/2019 